\title{
Assessment of potable water quality of surface water (tuikhur) and hand pumps in Siaha, southern Mizoram
}

\author{
John Blick*, Shiva Kumar \\ Department of Geology, Mizoram University, Tanhril 796004, India
}

\begin{abstract}
The present study focused on the physico-chemical characterization of potable water from hand pump (groundwater) and sub-surface (tuikhur) water in Siaha, Mizoram, during premonsoon season of 2017. $\mathrm{pH}$, total dissolved solids (TDS), electrical conductivity (EC), turbidity, total alkalinity $(\mathrm{TA})$, total hardness $(\mathrm{TH})$, iron $(\mathrm{Fe})$, magnesium $(\mathrm{Mg})$, calcium $(\mathrm{Ca})$, nitrate $\left(\mathrm{NO}_{3}\right)$, sulphate $\left(\mathrm{SO}_{4}\right)$ and chloride $(\mathrm{Cl})$ and their mean values obtained were $7.1,67.72 \mathrm{mg} / \mathrm{L}$, $103 \mathrm{mg} / \mathrm{L}, 1.8 \mathrm{NTU}, 43.9 \mathrm{mg} / \mathrm{L}, 45 \mathrm{mg} / \mathrm{L}, 0.30 \mathrm{mg} / \mathrm{L}, 6.24 \mathrm{mg} / \mathrm{L}, 7.21 \mathrm{mg} / \mathrm{L}, 0.23 \mathrm{mg} / \mathrm{L}, 3.27$ $\mathrm{mg} / \mathrm{L}$ and $9.51 \mathrm{mg} / \mathrm{L}$ respectively. The results revealed that all these water samples were well within permissible limits established by World Health Organization (WHO), and Bureau of Indian Standards (BIS). Hence, they are suitable for drinking purposes. However, Iron contents at few sites are found exceeding the permissible value of $0.3 \mathrm{mg} / \mathrm{L}$.
\end{abstract}

Key words: Siaha; Physico-chemical parameters; rock-water interaction; standard levels.
Received 12 June 2017 Accepted 21 August 2017

*For correspondence $\square$ : johnblick0316@gmail.com

\section{Introduction}

In Mizoram, the need for safe and sufficient drinking water is ensured from its sources and through Public Health Engineering Department (PHED), its supply to long distance or remote areas particularly, which are inaccessible. ${ }^{1-3}$ Potable water has been declining due to increasing human population, use of fertilizers, pesticides, manures, anthropogenic activities, etc. ${ }^{4,5}$

Drinking water is derived from a variety of sources such as surface water (rivers, lakes, reservoirs and ponds), groundwater (hand pumps, seepage and well) and rain water.,7 Rain water may not be recommended for direct domestic purposes as it contains minerals impurities.
There may have a chance for interaction between surface and sub-surface water with the rocks, soils and organisms on the earth as well as below the earth's surface. ${ }^{8,9}$ As a result, requisite minerals get included which are required for health to human beings. However, sometimes some toxic contents are being received by water in the form of heavy metals such as viz. arsenic, cadmium, nickel, etc.

Siaha is the headquarters of the southernmost district of Mizoram, India (Fig. 1). The district is bounded by Lunglei district on the north, Lawngtlai district on the south and on the south and east by Myanmar. The area under study is situated in Siaha town and its exact coordinates are $22.48^{\circ} \mathrm{N}$ and $92.97^{\circ} \mathrm{E}$ with an elevation of 2391 $\mathrm{ft}$. 


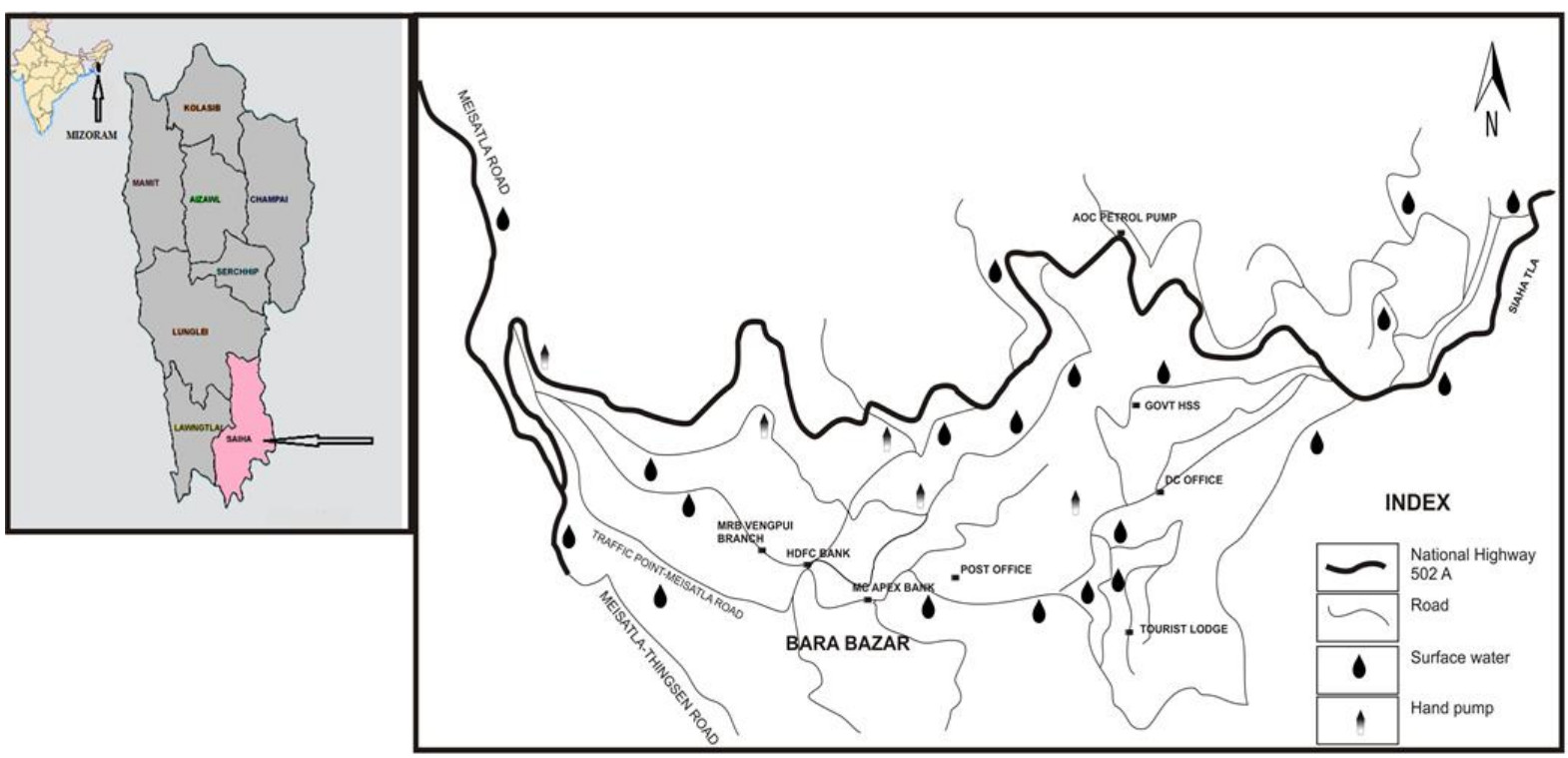

Fig. 1 | Location map of the study area.

The average temperature ranges between $8^{\circ}$ to $24^{\circ} \mathrm{C}$ in winter and it varies between 18 to $32^{\circ}$ $C$ in summer. Winter lasts from September and till January the next year. The area falls under the direct influence of south-west monsoon and heavy precipitation starts falling heavily from May to September. The soils type is generally the products of the weathered ferruginous sandstones, shale and limited alluvial and colluvial material transported by river/streams etc. They vary from sandy to load and clay to loam mixed with broken angular shape of varying size. The color of the soil varies from yellowish to brownish grey with varying depth.

The existing water for drinking purposes is mainly from those springs tapped through gravity drainage. Water supplied by the PHE department is not enough to meet the daily requirements of the people. Therefore, the people depend on secondary sources like rain water and surface water (tuikhur). Since these water are used without any treatment, the physicochemical characterization needs to be studied in comparison to the standards specified by BIS and $\mathrm{WHO}$, and to understand the sources of various contaminants in order to suggest remedies.

\section{Materials and Method}

The studies were conducted at Siaha town, Siaha district, Mizoram, India. The major native inhabitants are the Mara people. The water samples were collected in the pre-monsoon season in 2017 from the selected locations (Fig. 1). These samples have been taken for detailed hydrological and hydro-geochemical investigations. Various sources of potable water were identified. Out of 25 samples, 20 samples are from tuikhur and 5 samples are from hand pump. According to the recommendations of the APHA, AWWA and WEF, samples of potable water to be analyzed are representatives of the source from which water is drawn for different purposes. Before collection of the water samples, polythene bottles should be cleaned thoroughly, rinsed with distilled water and again rinsed with representative water samples. ${ }^{10}$

Two bottles of $250 \mathrm{ml}$ each for each location, one acidified with 2-4 $\mathrm{ml}$ of diluted $\mathrm{HNO}_{3}$ and non-acidified were collected. In situ testing of the water samples was done immediately at the site to find out the physico-chemical properties like $\mathrm{pH}$, turbidity, total dissolved solids (TDS), electrical conductivity (EC) and iron (Fe). Digital 
Table 1 | Water analyses results (physico-chemical characteristics) at Siaha.

\begin{tabular}{|c|c|c|c|c|c|c|c|}
\hline Samples & Location & pH & EC & TDS & TURB & TA & TH \\
\hline TK-01 & Vaipih-I & 7.2 & 69 & 51 & 2.6 & 42.21 & 39.16 \\
\hline TK-02 & Vaipih-II & 7.3 & 73 & 48 & 2.1 & 37.71 & 41.21 \\
\hline TK-03 & Medical Vaih-I & 6.8 & 102 & 79 & 2.5 & 42.18 & 37.32 \\
\hline TK-04 & Medical Vaih-II & 6.7 & 105 & 80 & 3.1 & 52.19 & 34.67 \\
\hline TK-05 & MRP Land & 7.2 & 125 & 75 & 1.7 & 44.43 & 43.62 \\
\hline TK-06 & Siaha Tla & 7.2 & 126 & 83 & 2.0 & 45.35 & 40.22 \\
\hline TK-07 & Siaha Tla, road to Tlapih & 7.1 & 87 & 48 & 1.2 & 56.46 & 35.34 \\
\hline TK-08 & N.Siaha, OlaTKi & 7.1 & 102 & 72 & 1.3 & 26.65 & 37.53 \\
\hline TK-09 & New Siaha E & 7.3 & 122 & 81 & 1.2 & 32.32 & 39.62 \\
\hline TK-10 & New Siaha W & 7.2 & 86 & 54 & 1.4 & 76.38 & 50.25 \\
\hline TK-11 & Chho Chho Paw & 6.9 & 92 & 53 & 1.3 & 37.68 & 54.32 \\
\hline HP-12 & KeimoTKi & 7.3 & 110 & 83 & 2.1 & 62.67 & 44.62 \\
\hline HP-13 & New Colony-I & 7.6 & 109 & 74 & 1.3 & 71.24 & 43.31 \\
\hline TK-14 & New Colony-II & 7.1 & 112 & 64 & 2.1 & 37.43 & 54.42 \\
\hline HP-15 & Golden Street, New Siaha & 7.3 & 123 & 92 & 2.0 & 39.56 & 55.37 \\
\hline TK-16 & Meisa Vaih & 7.1 & 107 & 64 & 2.1 & 34.78 & 46.62 \\
\hline HP-17 & College Vaih & 7.2 & 128 & 80 & 1.2 & 38.64 & 40.13 \\
\hline TK-18 & Circuit Vaih & 6.7 & 97 & 73 & 1.5 & 32.43 & 51.27 \\
\hline TK-19 & Council Vaih-I & 6.9 & 116 & 66 & 1.9 & 57.67 & 44.47 \\
\hline TK-20 & Council Vaih-II & 7.2 & 97 & 58 & 1.1 & 37.12 & 36.43 \\
\hline TK-21 & Meisa tla-I & 6.8 & 96 & 54 & 2.2 & 32.66 & 42.26 \\
\hline HP-22 & Meisa tla-II & 7.2 & 127 & 86 & 2.3 & 35.37 & 63.14 \\
\hline TK-23 & PWD, New Siaha & 6.8 & 131 & 92 & 1.5 & 46.54 & 64.26 \\
\hline TK-24 & A.R Viah & 7.1 & 68 & 40 & 1.6 & 40.11 & 44.28 \\
\hline TK-25 & Chakma Vaih & 7.3 & 86 & 43 & 1.7 & 37.67 & 43.23 \\
\hline MEAN & & 7.1 & 103.84 & 67.72 & 1.8 & 43.9 & 45.09 \\
\hline WHO & PREMISSIBLE LIMITS & $6.5-8.5$ & 600 & 500 & -- & -- & 500 \\
\hline BIS & PERMISSIBLE LIMITS & $6.5-8.5$ & 2000 & 2000 & 5 & 600 & 600 \\
\hline
\end{tabular}

* TK= Tuikhur; *HP= Hand pump

instruments made by Eutech Instruments were used to test the in situ values of $\mathrm{pH}$, TDS and EC. Turbidity values of the samples were measured using the Digital Nephelo Turbidity Meter-132 (Systronics) using formazine as standard. Total Fe was measured using the Water Testing Kit made by Transchem Agritech Limited. Total hardness, $\mathrm{Ca}, \mathrm{Mg}$, total chloride, total alkalinity and sulphate were analyzed by titrimetric method. The determination of $\mathrm{NO}_{3}$ concentration in the samples was done by UVspectrophotometric method.

\section{Results and Discussion}

Results of all the potable sources in the study area have been classified into physical and chemical properties and presented in the Table 1 and 2 respectively.

It was seen that the $\mathrm{pH}$ varied from 6.7-7.6 (Table 1), which are found to be well within the acceptance limit for drinking water (6.5-8.5) as specified by the BIS ${ }^{11}$ and $\mathrm{WHO}^{12}$. The electrical conductivity values varied from 68-131 $\mu \mathrm{S} / \mathrm{cm}$. The lower values of EC may be due to the presence of lesser amounts of dissolved salts indicative of less solubility of minerals and ions from the host rock and has insignificant rock-water intercalation. Further, it characterizes dominance of more silica content in the host rock. However, the Environmental Protection Agency (EPA) considers electrical conductivity as a secondary maximum contaminant level (SMCL); it does not have a direct impact on health. ${ }^{13}$ The 
Table 2 | Water analyses results (physico-chemical characteristics) at Siaha.

\begin{tabular}{|c|c|c|c|c|c|c|c|}
\hline Samples & Location & $\mathrm{TCl}$ & $\mathrm{Fe}$ & $\mathrm{Ca}$ & Mg & $\mathrm{SO}_{4}$ & $\mathrm{NO}_{3}$ \\
\hline TK-01 & Vaipih-I & 6.21 & 0.02 & 5.11 & 4.21 & 1.15 & 0.12 \\
\hline TK-02 & Vaipih-II & 6.32 & 0.01 & 5.21 & 4.43 & 1.24 & 0.11 \\
\hline TK-03 & Medical Vaih-I & 7.21 & 0.01 & 6.13 & 6.28 & 2.32 & 0.31 \\
\hline TK-04 & Medical Vaih-II & 8.13 & 0.02 & 4.24 & 4.28 & 2.31 & 0.21 \\
\hline TK-05 & MRP Land & 7.58 & 0.02 & 6.31 & 3.49 & 3.23 & 0.15 \\
\hline TK-06 & Siaha Tla & 8.32 & 0.01 & 6.26 & 4.42 & 3.08 & 0.17 \\
\hline TK-07 & Siaha Tla, road to Tlapih & 9.24 & 0.01 & 9.03 & 5.65 & 3.12 & 0.22 \\
\hline TK-08 & N.Siaha, OlaTKi & 9.05 & 0.01 & 6.11 & 3.42 & 2.35 & 0.26 \\
\hline TK-09 & New Siaha E & 8.26 & 0.02 & 4.27 & 4.41 & 3.43 & 0.37 \\
\hline TK-10 & New Siaha W & 11.07 & 0.02 & 7.32 & 6.34 & 2.18 & 0.25 \\
\hline TK-11 & Chho Chho Paw & 9.44 & 0.03 & 8.76 & 7.18 & 3.28 & 0.21 \\
\hline HP-12 & KeimoTKi & 8.17 & 0.5 & 10.12 & 8.77 & 5.02 & 0.28 \\
\hline HP-13 & New Colony-I & 7.87 & 0.8 & 7.54 & 9.28 & 6.06 & 0.26 \\
\hline TK-14 & New Colony-II & 11.19 & 0.2 & 9.36 & 12.13 & 5.12 & 0.18 \\
\hline HP-15 & Golden Street, New Siaha & 12.54 & 1.7 & 8.44 & 11.31 & 4.68 & 0.24 \\
\hline TK-16 & Meisa Vaih & 13.21 & 0.04 & 5.42 & 5.23 & 2.14 & 0.35 \\
\hline HP-17 & College Vaih & 14.28 & 2.1 & 7.64 & 10.34 & 5.27 & 0.27 \\
\hline TK-18 & Circuit Vaih & 11.37 & 0.02 & 6.59 & 4.67 & 3.41 & 0.19 \\
\hline TK-19 & Council Vaih-I & 10.26 & 0.03 & 4.89 & 3.54 & 2.47 & 0.18 \\
\hline TK-20 & Council Vaih-II & 8.87 & 0.04 & 6.87 & 6.35 & 3.09 & 0.19 \\
\hline TK-21 & Meisa tla-I & 9.53 & 0.02 & 7.27 & 4.42 & 2.54 & 0.27 \\
\hline HP-22 & Meisa tla-II & 10.21 & 1.9 & 11.07 & 9.46 & 6.05 & 0.31 \\
\hline TK-23 & PWD, New Siaha & 12.12 & 0.02 & 11.35 & 6.62 & 3.19 & 0.27 \\
\hline TK-24 & A.R Viah & 8.24 & 0.01 & 8.27 & 4.67 & 3.11 & 0.22 \\
\hline TK-25 & Chakma Vaih & 9.21 & 0.02 & 6.85 & 5.28 & 2.13 & 0.16 \\
\hline MEAN & & 9.51 & 0.3 & 7.21 & 6.24 & 3.27 & 0.23 \\
\hline WHO & PREMISSIBLE LIMITS & 200 & 0.1 & 75 & 30 & 250 & 50 \\
\hline BIS & PERMISSIBLE LIMITS & 1000 & 0.3 & 200 & 100 & 400 & 45 \\
\hline
\end{tabular}

* TK= Tuikhur; *HP= Hand pump

electrical conductivity values are generally higher for sub-surface water (tuikhur water) in comparison to the groundwater (hand pump). The value with $400 \mu \mathrm{S} / \mathrm{cm}$ of electrical conductivity at $25^{\circ} \mathrm{C}$ is considered fittable for human consumption, but more than $1500 \mu \mathrm{S} / \mathrm{cm}$ at the same temperature may cause corrosion of iron structure. ${ }^{14}$ Since conductivity is related to the content of all cation and anion or total dissolved solid (TDS), it can be regarded as a crude indicator of water quality for many purposes. The geochemical rock-water intercalation may attribute the value of TDS higher due to the adding of a number of electrolytes to the water bodies. ${ }^{15}$

The TDS value obtained in the area ranged from $40-90 \mathrm{mg} / \mathrm{L}$ (Fig. 2A). According to WHO, the standard permissible limit for TDS is 2000 $\mathrm{mg} / \mathrm{l}$. Water at a TDS level of above $500 \mathrm{mg} / \mathrm{l}$ is unsuitable for flora and tastes unpleasant to drink. In the present study TDS values were found well within the standard permissible limit. Since total dissolved solids is directly proportional to conductivity, higher value of TDS in water indicates the presence of various kinds of minerals and ionized solute. For turbidity, it is observed that all the values of the stations have slightly higher than the desirable limit but still within the permissible limit of 5NTU. The hardness measured in the water samples were rather low, ranging between $34 \mathrm{mg} / \mathrm{L}$ and $64 \mathrm{mg} / \mathrm{L}$. The measured were all below the WHO limit of 600 $\mathrm{mg} / \mathrm{L}$. Soft water less than $100 \mathrm{mg} / \mathrm{L}$ of hardness 


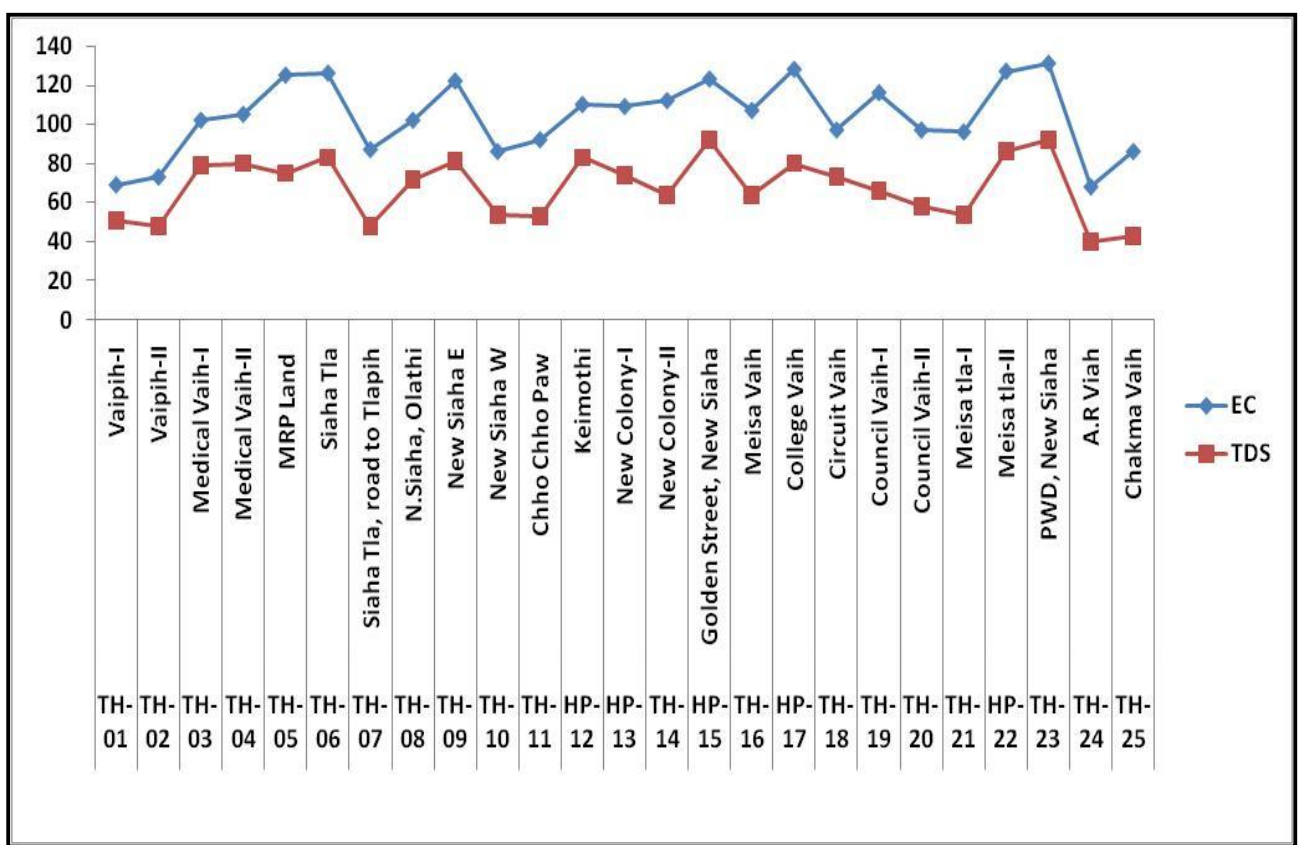

Fig. 2A | Plot of physical data (electrical conductivity and total dissolved solids).

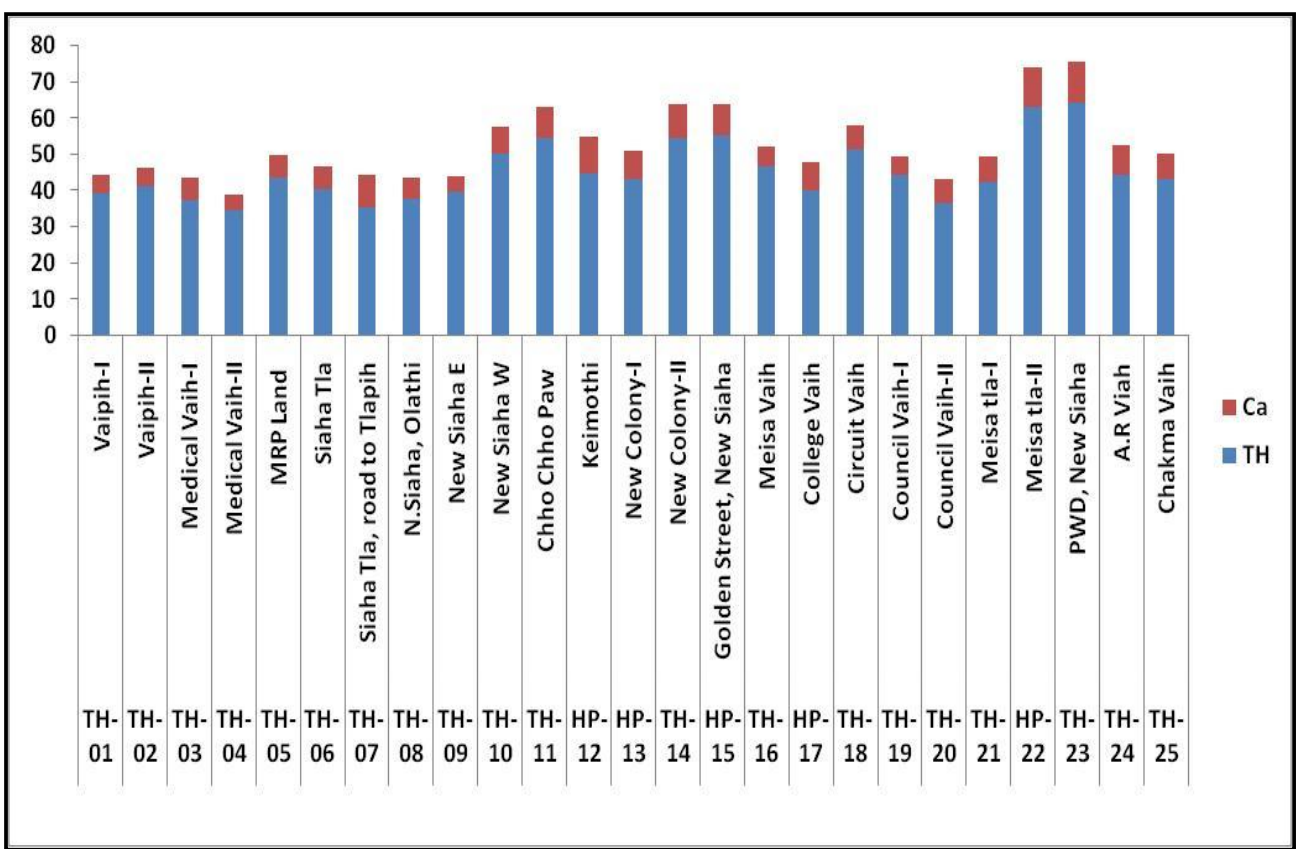

Fig. 2B | Plot of chemical data (calcium and total hardness). 


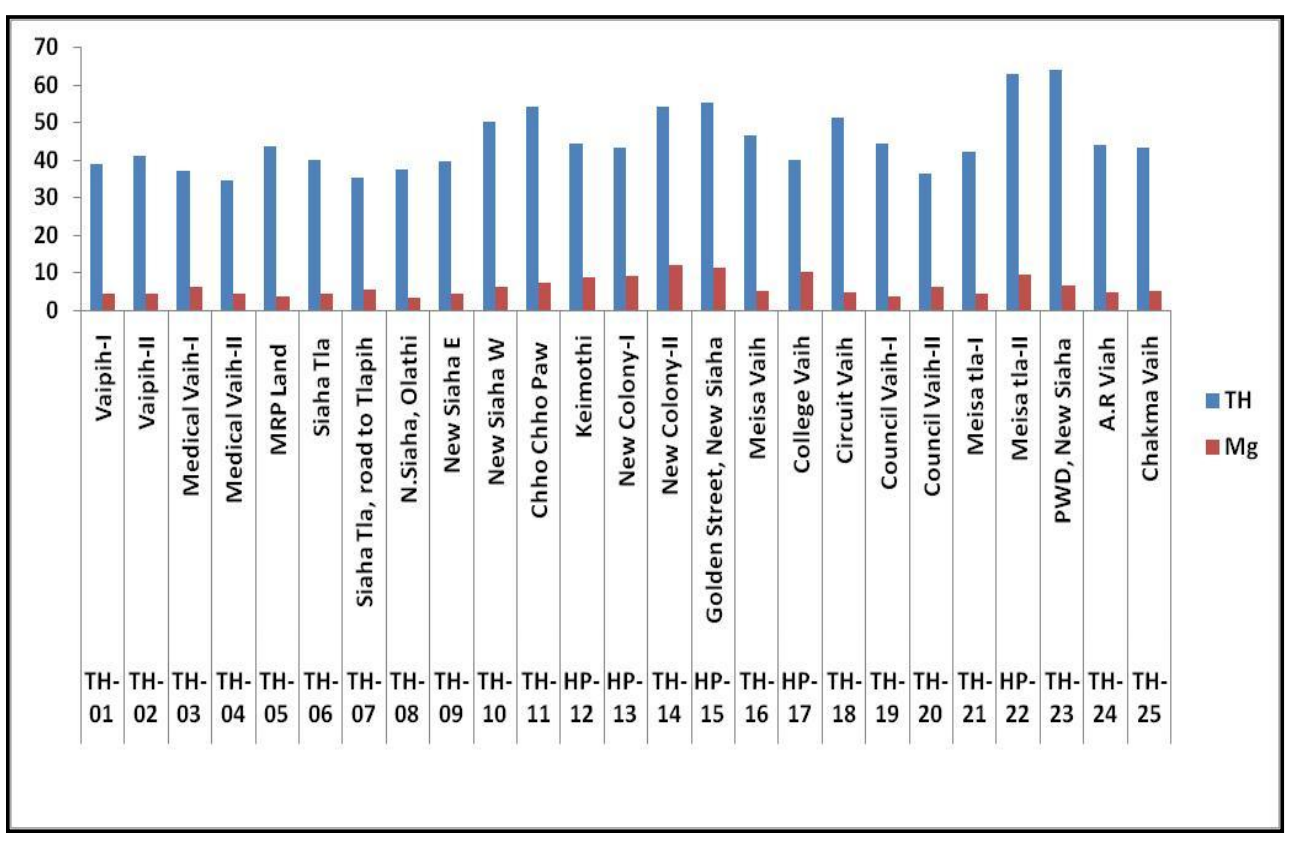

Fig. 2C | Plot of chemical data (total hardness and magnesium).

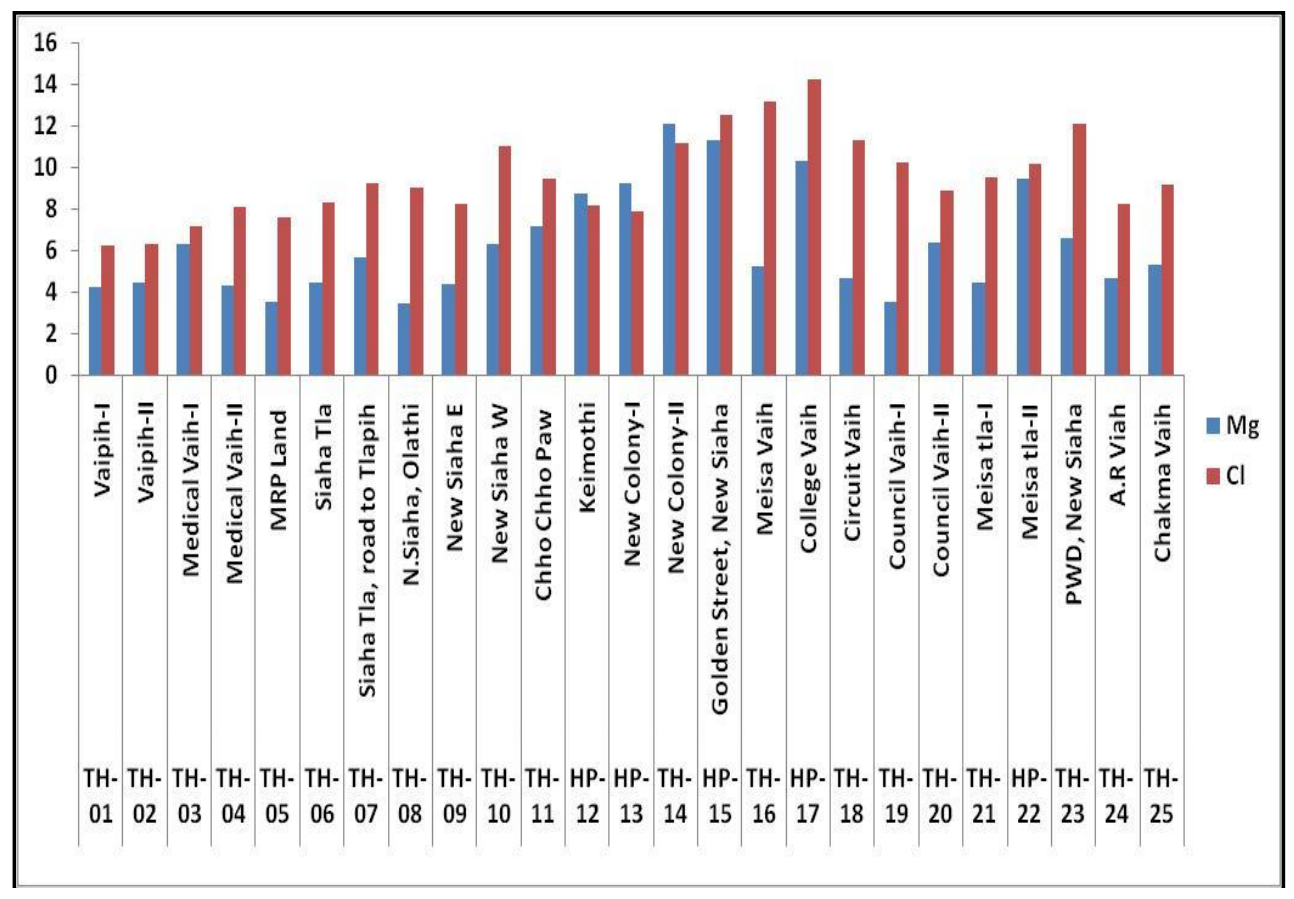

Fig. 2D | Plot of chemical data (magnesium and chloride). 


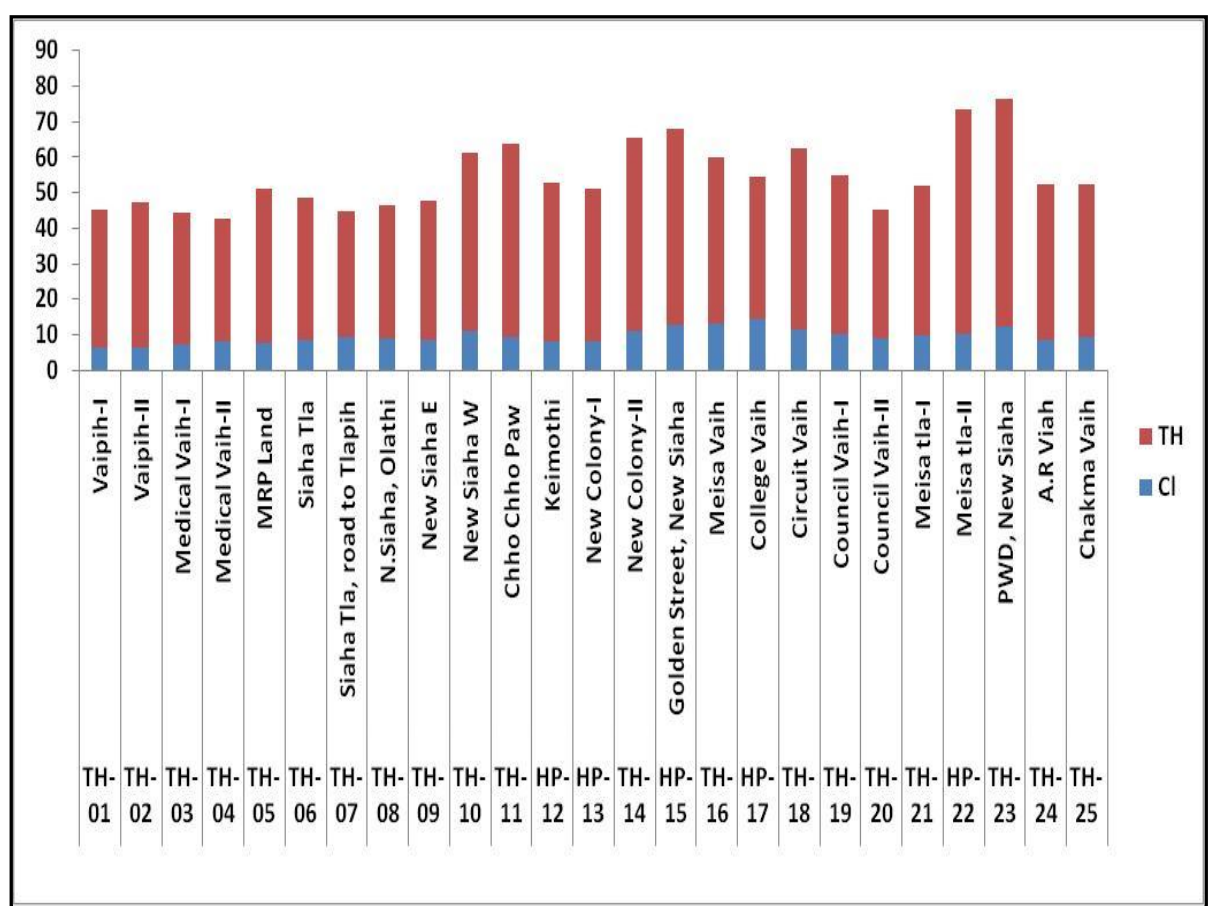

Fig. 2C | Plot of chemical data (total hardness and magnesium).

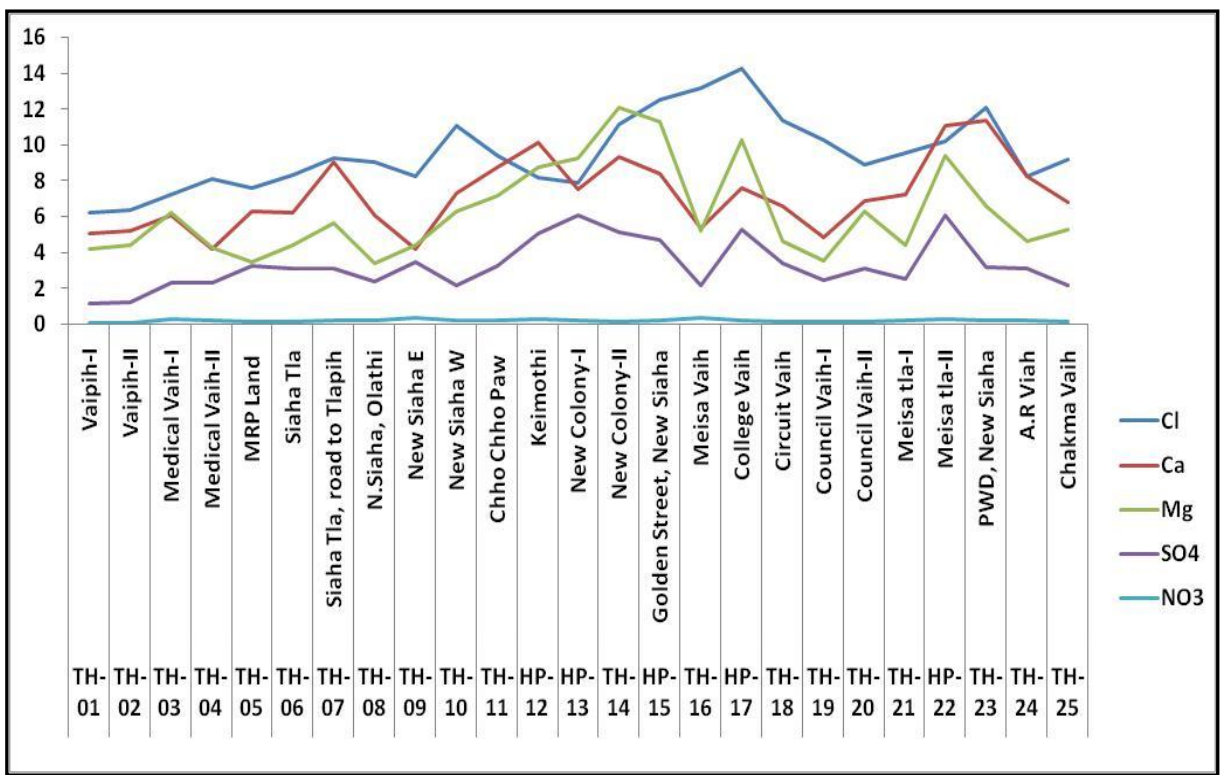

Fig. 2F | Plot of chemical data (chloride, calcium, magnesium, sulphate and nitrate). 
may have low buffering capacity and more corrosive. ${ }^{16}$

In natural waters, alkalinity is due to free hydroxyl ions and dissolution of $\mathrm{CO}_{2}$ in water. ${ }^{17}$ In addition, it is a measure of the buffering capacity of water, or the capacity of bases to neutralize acids. It is used in determining the ability of stream to neutralize acidic pollution from rainfall or wastewater. In the samples analyzed, total alkalinity was found to be slightly low ranged from $26-76 \mathrm{mg} / \mathrm{L}$. The values of total alkalinity having less than $200 \mathrm{mg} / \mathrm{L}$ are desirable for drinking and domestic purposes. Chloride in water is one of the major inorganic anions. The concentration of chloride which exceeds the level of $250 \mathrm{mg} / \mathrm{L}$ may produce salty taste; however, it does not cause any hazard to human health. The concentration of total chloride (TCl) in all the stations are much lower $(6-14 \mathrm{mg} / \mathrm{L})$ than the desirable limits value of $250 \mathrm{mg} / \mathrm{L}$ (Fig. 2D, 2E). Values of chloride ion in normal portable water are less than $30 \mathrm{mg} / \mathrm{L}$, whereas higher values commonly indicate the admixture of mineralized waters or anthropogenic pollution. ${ }^{18}$

The standard level of iron prescribed by WHO is $0.3 \mathrm{mg} / \mathrm{L}$. The concentration of iron in groundwater (hand pumps) samples is much more than the sub-surface water. All of the hand pumps samples were found exceeding the standard level of iron. The Environmental Protection Agency considers iron as a secondary contamination; declare that it does not have a direct impact on human health. The secondary maximum contaminant level of iron set out by the WHO is merely a guideline and not a federal standard. Idaho's groundwater (well) has exceeded quite amount of iron (15 mg/L), however the level is still not enough to cause physical harm..$^{19}$ The concentration of nitrate in all the samples is quite low ranged from $0.11-0.37 \mathrm{mg} / \mathrm{L}$ as compare to the standard level of $45 \mathrm{mg} / \mathrm{L}$ (Fig. $2 \mathrm{~F})$. The low concentration of nitrate indicates less use of nitrogenous fertilizers. ${ }^{20}$ The major cations like calcium and magnesium are found to be in ranged of 4.24-11.35 and 3.42-12.13 mg/L having mean value of 6.87 and $5.28 \mathrm{mg} / \mathrm{L}$ respectively. In all the samples, it can be seen that all the values of these cations ( $\mathrm{Ca}, \mathrm{Mg}$ ) are much lower than the standard value, but are well within the desirable limits (Fig. 2F). High level of Sulphate in drinking water may contribute to the corrosion of distribution system, and hence causes water a bad taste as well as purgative in humans. ${ }^{21}$ The values of Sulphate were generally low, ranging between $1.15 \mathrm{mg} / \mathrm{L}-6.06 \mathrm{mg} / \mathrm{L}$ with a mean of $3.11 \mathrm{mg} / \mathrm{L}$. The WHO permissible limit is $200 \mathrm{mg} / \mathrm{L}$.

\section{Conclusion}

The present investigations indicate that all the physico-chemical parameters of the samples were within the permissible limits as per standards prescribed by WHO and BIS. Though Iron concentration in hand pump samples exceeded the standard level, it is considered as the secondary contamination which means that it does not have a direct impact on human health. It is concluded that all the tuikhurs and hand pumps are fit and suitable to serve as water source for human consumptions and household purposes.

\section{References}

I. Blick, J., Kumar, S., Bharati, V.K. \& Kumar, S. (2016). Status of arsenic contamination in potable water in Chawngte, Lawngtlai district, Mizoram. Science Vision, I6(2), 74-8I.

2. Kumar, S., Bharati, V.K., Singh, K.B. \& Singh, T.N. (2010). Quality assessment of potable water in the town of Kolasib, Mizoram (India). Environmental Earth Science, 6I, II5-I2I.

3. Blick, J., Kumar, S., Singh, K.B. \& Laltlankima. (2016). Arsenic contamination in potable water of Chawngte, Lawngtlai district, Mizoram. In: Solid waste management and safe drinking water in context of Mizoram and other states in India. (Rajendra Prasad, eds), Educreation Publishing, Shubham Vihar, Mangla, Bilaspur, Chhattisgarh, pp. 38-47.

4. Carpenter, S.R., Karaco, N.F., Corell, D.L., Howarth, R.W., Sharpley, A.N. \& Smith, V.H. (1998). Non-point pollution of surface water with phosphorus and nitrogen. Ecological Applications, 8, 559-568.

5. Chen, J., Wang, F., Xia, X. \& Zhang, L. (2002). Major 
element chemistry of the Changiang (Yangtze River). Chemical Geology, 187, 23I-255.

6. Kumar, S., Baier, K., Jha, R. \& Arab, J. (2013). Status of arsenic contamination in potable water of Northern areas of Mizoram state and its adjoining areas of Southern Assam, India. Arabian Journal of Geosciences, 6(2), 383-393.

7. Laltlankima, Blick, J., Kumar, S. \& Singh, K.B. (2016). Status of potable water quality at selected sites of Aizawl City, Mizoram. In: Solid waste management and safe drinking water in context of Mizoram and other states in India. (Rajendra Prasad, eds), Educreation Publishing, Shubham Vihar, Mangla, Bilaspur, Chhattisgarh, pp. 33-37.

8. Kumar, S., Singh, K.B. \& Bharati, V.K. (2007). Potable water status in Aizawl city, Mizoram state, India. Journal of Geography Association of Mizoram, Geographic, 2, 85-108.

9. Kumar, S., Singh, K.B. \& Bharati, V.K. (2009). Assessment of spring water quality in Aizawl city, Mizoram. Journal of Applied Hydrology, 22(3-4), 6-II.

Io. APHA, AWWA \& WEF (2005). Standard methods for the examination of water and waste water analysis. $2 \mathrm{O}^{\text {th }}$ Edition. American Public Health Association, Washington, DC.

II. BIS (IS: I0500: 2012). Specification for Drinking water. Bureau of Indian Standards, New Delhi.

I2. WHO (20II). Guidelines for drinking water quality. $4^{\text {th }}$ Edition.

13. EPA (2OI2) Conductivity in water: Monitoring and Assessment. Retrieved from http://water.epa.gov/type/ $\mathrm{rsl} /$ monitoring/vms59.cfm.
I4. Pavan, K.P., Raghuveer, Y.P \& Ashwitha, K. (2013). Bacteriological and Physico-Chemical Quality of Main Drinking Water Sources. Polish Journal of Environmental Studies, 22(3), 825-830.

I5. Gupta, S., Maheto, A., Roy, P., Datta, J.K. \& Saha, R.N. (2008). Geochemistry of groundwater Burdwan District, West Bengal, India. Environmental Geology, s3, I27I-I282.

16. WHO. (2003). Hardness in drinking water. Background document for preparation of WHO guidelines for drinking water quality, Geneva.

17. Frank, N. (1987). Water quality hand book, Mc Graw bill publication, New York, $2{ }^{\text {nd }}$ Edition, I3-19.

18. Matthess, G. (1982). The properties of groundwater. John Willey \& Sons, New York, 406.

19. Alex, C. \& Mahler, R.L. (2006). Iron in drinking water. University of Idaho, Pacific Northwest, 589, I-2.

2o. Basu, K.N., Padmalal, D., Maya, K., Sareeja, R. \& Aurn, P.R. (2007). Quality of surface and groundwater around tile and brick clay mines in Chalakudy river basin, southwestern India. Journal of the Geological Society of India, 69, 279-284.

2I. Gyamfi, E.T., Ackah, M., Anim, A.K., Hanson, J.K., Pattah, L.K., Enti, B.S., Adjei, K.Y. \& Nyarko, E.S. (2012). Chemical analysis of potable water samples from selected suburbs of Accra, Ghana. Proceedings of the International Academy of Ecology and Environmental Sciences, 2(2), II8-I27. 